\title{
Peran Notaris/PPAT Dalam Pembuatan Akta Pembagian Harta Warisan Terhadap Ahli Waris Yang Berbeda Agama
}

\author{
Diah Ragil Kusuma ${ }^{*}$, Arif Hidayat**, Munsharif Abdul Chalim ${ }^{* * *}$ \\ * Mahasiswa Program Magister \\ diahragilkusuma1204@gmail.com \\ ** Mahasiswa Program Magister \\ arif_hidayat_1985@yahoo.co.id \\ *** Dosen Fakultas Hukum UNISSULA \\ (S2) Kenotariatan Fakultas Hukum UNISSULA, Semarang email : \\ (S2) Ilmu Hukum, Fakultas Hukum UNISSULA, Semarang, e-mail:
}

\section{ABSTRAK}

Kewajiban dalam melaksanakan wasiat wajibah itu bersifat Qadhai, disini dapat diartikan bahwa tidak hanya sebagai tanggung jawab seseorang dalam melaksanakan perintah agama, namun wasiat wajibah tersebut dapat dipaksakan apabila ia lalai dalam melaksanakannya karena sudah menyangkut kepentingan umum.

Peran notaris dalam membuat akta pembagian harta waris terhadap ahli waris non muslim yakni dengan membuatkan Akta Keterangan Waris yang di dalamnya menjelaskan pemberiannya melalui wasiat wajibah. Demikian pula yang menjadi landasan yuridis atas pemberian wasiat wajibah kepada ahli waris non muslim oleh Putusan Mahkamah Agung RI Nomor: 368 K/AG/1995, tanggal 16 Juli 1998 yang telah menetapkan bahwa seorang anak perempuan yang beragama Nasrani berhak pula mendapat harta warisan pewaris, tidak melalui warisan melainkan melalui wasiat wajibah. Dan besar perolehannya adalah sama dengan bagian seorang anak perempuan, bukan 1/3 dari harta warisan dan bukan pula 3/4 bagian dari perolehan anak perempuan pewaris. Selanjutnya Putusan Mahakamah Agung RI Nomor: 51 K/AG/1999, tanggal 29 September 1999 yang telah memberikan pertimbangan: "Menimbang, bahwa namun dengan demikian Mahkamah Agung berpendapat bahwa putusan Pengadilan Tinggi Agama Yogyakarta harus diperbaiki, karena seharusnya Pengadilan Tinggi Agama Yogyakarta memperbaiki amar putusan Pengadilan Agama Yogyakarta mengenai ahli waris non muslim, mereka berhak mendapat warisan melalui wasiat wajibah yang kadar bagiannya sama dengan bagian ahli waris muslim." Kata Kunci : Notaris, Wasiat Wajibah, Non Muslim.

\section{ABSTRACT}

Obligation in carrying out the mandate is Qadhai, here it can be interpreted that not only as a person's responsibility in carrying out religious orders, but the will is compulsory if he neglects in carrying it out because it is related to the public interest.

Notary's role in making the deed of dividing the heirs against non-Muslim heirs by making the Deed of Inheritance Statement which in it explains its grant through the mandatory testament. Likewise, the juridical basis for the provision of a mandatory will to non-Muslim heirs by the Supreme Court Decision Number 368 K / AG / 1995, dated July 16, 1998 which has stipulated that a Christian girl is entitled to also get the inheritance, not through inheritance but through a mandatory will. And the gains are equal to the share of a daughter, not $1 / 3$ of the estate and not the part of the acquisition of the daughter of the testator. Furthermore, the Supreme Court Decision Number 51 / K / 1999 dated 29 September 1999 has given consideration: "Considering that, however, the Supreme Court is of the opinion that the decision of the Yogyakarta High Religious Court must be improved, since the Religious High Court of Yogyakarta should have improved the amar the decision of the Religious Court of Yogyakarta concerning the non-Muslim heirs, they are entitled to inheritance through a mandatory testament whose content is equal to that of the Muslim heirs".

Keyword : Notary, Mandatory Testament, Non-Muslim.

\section{PENDAHULUAN}

Permasalahan waris merupakan salah satu permasalahan yang sampai saat ini sering menimbulkan sengketa yang menyebabkan perpecahan dalam keluarga. Hal ini umumnya karena persepsi bahwa waris sangat erat hubungannya dengan harta dengan pendapat ahli waris pasti akan menerima harta dari pewaris sehingga menjadi pemicu perpecahan dalam keluarga.

Masalah waris sesungguhnya sudah diatur sedemikian dalam peraturan-peraturan. Diantara peraturan atau hukum, baik agama maupun negara, permasalahan waris termasuk permasalahan yang diatur secara jelas dan rinci bahkan dengan 
kepastian timbulnya konflik yang berhubungan dengan waris.

Di dalam hukum Islam mengatur juga mengenai pemberian maupun pembagian harta, yaitu hukum kewarisan Islam, wasiat dan hibah. Dalam beberapa literatur hukum islam ditemui beberapa istilah untuk menamakan Hukum Kewarisan Islam, seperti fikih mawaris, hukum kewarisan dan ilmu faraid. Perbedaan dalam penamaan ini terjadi karena perbedaan arah yang dijadikan titik utama dalam pembahasan. Kompilasi Hukum Islam membedakan antara harta warisan dengan harta peninggalan. Pengertian harta warisan terdapat pada Pasal 1 huruf e yaitu : "Harta waris adalah harta bawaan ditambah bagian dari harta bersama setelah digunakan untuk keperluan pewaris selama sakit sampai meninggalnya. Biaya pengurusan jenazah (tajlis), pembayaran hutang dan pembelian untuk kerabat". Sedangkan pengertian dari harta peninggalan terdapat pada pasal huruf $d$ adalah : "Harta peninggalan adalah harta yang ditinggalkan oleh pewaris baik yang berupa harta benda yang menjadi miliknya maupun hak-haknya".

Menurut Prof T.M Hasby As-Shidiqi dalam bukunya hukum waris, Fiqih mawaris adalah ilmu yang dengan dia dapat diketahui orang-orang yang mewarisi, orang-orang yang tidak dapat mewarisi kadar yang diterima oleh masing-masing ahli waris serta cara pengambilan nya. ${ }^{1}$ Ilmu faraid (waris islam) adalah sebuah cabang ilmu pengetahuan yang membahas tentang aturan pembagian warisan seseorang yang telah meninggal dunia kepada ahli warisnya yang masih hidup baik harta maupun hakhaknya yang legal sesuai syariat islam.

Ibnu Rusyd mendefinisikan Ilmu Faraidh adalah ilmu untuk mengetahui cara membagi harta peninggalan seseorang yang telah meninggal dunia kepada yang berhak menerimanya. ${ }^{2}$ Syekh Muhammad Ali As. Sobury dalam Al Mawarist FisSyariatil Islamiyah Fi Daril Kitab Was Sunnah menyatakan bahwa ilmu faraid adalah ilmu pengetahuan yang memberikan informasi tentang pemindahan kepemilikan harta yang ditinggalkan oleh pewaris kepada ahli warisnya dalam bentuk harta benda atau hak-hak materi lainnya. ${ }^{3}$

Adapun menurut Dr. Wahban AZ-Zauhayli (ahli ilmu faraidh) ilmu faraidh adalah aturan-aturan hukum fikih dan perhitungannya yang memberi informasi tentang jatah setiap ahli waris dari harta

\footnotetext{
${ }^{1}$ T.M Hasbi As-Shiddiqi,2001, Fiqih Mawaris, Semarang : Pustaka Rizki Putra,hlm.5

2 Ibnu Rusyd,1995, Bidayatul Mujtahid, Bairut:Darul Fkri.hlm 276

${ }^{3}$ Ahmad Bisyri Syakur.L.C MA,2015, Mudah Memahami Hukum Islam, Visi Media Pustaka, hlm3
}

warisan, Syeikh Sayyid Sabih dalam kitab Fiqih Sunnah (hal 434) menjelaskan bahwa ilmu faraidh adalah ilmu pengetahuan tentang jatah warisan yang telah ditentukan oleh Allah SWT. ${ }^{4}$

Hukum Waris Islam menurut KHI (Kompilasi Hukum Islam) pada Pasal 171 huruf (a) adalah "hukum yang mengatur tentang pemindahan hak pemilikan harta peninggalan (tirkah) pewaris, menentukan siapa-siapa yang berhak menjadi ahli waris dan beberapa bagiannya masing-masing. Jadi hukum waris islam adalah seperangkat aturan tentang proses pembagian harta peninggalan orang yang telah meninggal dunia dan menentukan ahli waris mana saja yang berhak untuk mendapatkan harta warisan tersebut dan juga ilmu ini mempelajari bagian masing-masing dari harta peninggalan tersebut sesuai dengan ketetapan ajaran islam. ${ }^{5}$

Dalam perkembangan pembagian harta waris di masyarakat juga ditemukan kesepakatan antara ahli waris yang dilakukan setelah pembagian sesuai syariat adalah kepemilikan resmi pribadi masingmasing sehingga ahli waris tersebut bebas memperlakukan kepemilikannya sesuai kemaslahatan yang diinginkan. Adapun sebelum pembagian secara syariat, harta waris itu masih berstatus milik Allah SWT. Sehingga tidak boleh diatur sesuai keinginan manusia. Kesepakatan pembagian harta warisan sebelum dibagikan adalah haram, sedangkan kesepakatan pemanfaatan harta waris setelah pembagian adalah halal dan dianjurkan agar lebih membawa manfaat yang besar, misalnya : kesepakatan ahli waris untuk bersepakat dalam sebuah usaha bisnis atau kesepakatan untuk berwakaf, sedekah, infak, atau kesepakatan untuk membantu salah seorang keluarga tidak mampu.

Sedangkan wasiat adalah pesan seseorang untuk memberikan suatu materi yang hanya dapat dimiliki, setelah pemberi wasiat itu meninggal dunia. Wasiat telah sah disampaikan oleh seseorang, meskipun hanya secara lisan tanpa tulisan karena hukum dasar pewasiatan memang dengan lisan.

Wasiat wajibah merupakan kebijakan penguasa yang bersifat memaksa untuk memberikan wasiat kepada orang tertentu dalam keadaan tertentu . wasiat wajibah adalah suatu wasiat yang diperuntukkan kepada ahli waris atau kerabat yang tidak memperoleh bagian harta warisan dari orang yang wafat, karena adanya suatu halangan syara. ${ }^{6}$

Suparman dalam bukunya fiqih mawaris (Hukuman Kewarisan Islam) mendefinisikan wasiat

\footnotetext{
${ }^{4}$ Ibid

${ }^{5}$ Aulia Muthiah, S.HI.MH, Hukum Islam Dinamika Seputar Hukum Keluarga, 2017,Pustaka Baru, hlm 147

${ }^{6}$ Abdul Aziz Dahlan, Ensiklopedi Hukum Islam, Jakarta, PT Ikhtiar Baru Van Hoeve,Jilid 6 Hal 1930
} 
wajibah sebagai wasiat yang pelaksanaannya tidak dipengaruhi atau tidak bergantung pada kehendak si yang meninggal dunia.' Abu muslim Al Ashfahany berpendapat bahwa wasiat diwajibkan untuk golongan-golongan yang tidak mendapatkan harta pusaka. ${ }^{6}$ bahwa apabila tidak dilakukan wasiat oleh pewaris kepada kerabat yang tidak mendapatkan harta pewaris, maka hakim harus bertindak sebagai pewaris yang memberikan bagian dari harta peninggalan pewaris kepada kerabat yang tidak mendapatkan harta pusaka dalam bentuk wasiat yang wajib.

Dalam Undang-Undang Nomor 2 Tahun 2014 tentang Jabatan Notaris, pada Pasal 1 Ayat yang dimaksud dengan notaris adalah pejabat umum yang berwenang untuk membuat akta autentik dan memiliki kewenangan lainnya sebagaimana dimaksud dalam Undang-Undang ini atau berdasarkan UndangUndang lainnya.

Berkenaan dengan ini berdasarkan pasal 943 UUJN ditentukan bahwa Notaris yang menyimpan surat-surat wasiat diantara surat-surat aslinya, dalam bentuk apapun juga, setelah meninggalnya pewaris, harus memberitahukannya kepada orang-orang yang berkepentingan.

Dengan demikian berdasarkan uraian diatas dapat disimpulkan bahwa adanya penghalang tidak saling mewarisi menurut hukum Islam diantaranya adalah perbedaan agama, antara pewaris dengan ahli waris. Perbedaan agama sebagai penghalang untuk dapat saling mewarisi dalam hukum kewarisan sesuai dengan muatan hadits memang sudah tidak bisa dirubah lagi, akan tetapi tentunya dalam perkembangan selanjutnya ketika realitas sosio kultural telah berbeda dengan masa pada saat hadits itu diturunkan hendaknya dibedakan dengan pembunuhan atau fitnah yang terbukti atau diakui oleh pelakunya yang secara universal diakui dengan kejahatan terhadap manusia, sehingga apabila pelakunya dihukum tidak dapat mewarisi pewarisnya yang dibunuh, dianiaya, atau difitnah, maka tidak akan ada yang mengakuitisi bahwa hukum Islam tidak adil.

Perbedaan agama bukanlah merupakan kejahatan terhadap kemanusiaan tetapi menyangkut keyakinan akan kebenaran ajaran Islam telah mengajarkan demikian. Oleh sebab itu apabila ahli waris yang berbeda agama dengan pewarisnya yang muslim tidak mendapatkan bagian, maka hukum Islam akan dianggap sebagai hukum yang tidak adil.

\footnotetext{
${ }^{7}$ Suparman, Fiqih Mawaris Hukum Kewarisan Islam, Jakarta, Gaya Media Pratama,1997, hal 163
}

Disebutkan didalam Al-qur`an surat Al-Baqarah ayat 180 yang artinya jika seseorang tidak berwasiat maka kaum kerabat yang tinggal wajib untuk mengeluarkan jumlah tertentu dari harta warisan yang mereka anggap layak untuk kaum kerabat yang tidak berhak mewarisi.

Wasiat dalam hukum kewarisan adalah khusus diberikan kepada orang-orang yang tidak dapat mewarisi karena sebab terhalang mewarisi walaupun berbeda agama, apabila masuk Islam seorang kafir kemudian datang pada kematiannya, sementara kedua orang tuanya masih tetap kafir, maka kepadanya diharuskan untuk berwasiat untuk melunakkan hati kedua orang tuanya, sebagaimana perintah Allah SWT untuk senantiasa berbuat baik kepada orang tua walaupun keduanya tetap kafir.

Dari uraian diatas jelaslah bahwa kedua orang tua dan kerabat yang tidak bisa mewarisi disebabkan karena adanya salah satu penghalang, apakah karena perbudakan, beda agama atau terhalang oleh ahli waris lain, wajib diberi wasiat, apabila seorang muslim pada saat hidupnya muslim pada saat hidupnya tidak berwasiat.

\section{Metode Penelitian}

Pada penulisan jurnal ini adapun metode pendekatan yang digunakan dalam penelitian ini adalah metode pendekatan Yuridis Sosiologis. Pendekatan ini dilakukan untuk memahami hukum dalam konteks masyarakat yaitu suatu pendekatan yang bersifat non doktrinal. Kualitatif yaitu jenis dan cara observasi dipakai sebagai observasi yang dimulai dari cara kerja deskriptif, kemudian observasi terfokus dan pada akhirnya observasi terseleksi. Dengan pendekatan masyarakat, yang kemudian didukung dengan data-data sekunder sebagai refrensi dalam penelitian yang diperoleh dari bukubuku yang kaitannya dengan penulisan penelitian. Untuk menganalisis data yang telah terkumpul dalam penelitian ini dengan menggunakan metode deskriptif kualitatif, yaitu suatu metode dalam meneliti status kelompok manusia, suatu objek, kondisi, sistem pemikiran ataupun suatu kelas peristiwa pada masa sekarang, yang bertujuan untuk membuat deskripsi, gambaran atau lukisan secara sistematis, faktual dan akurat mengenai fakta yang ada serta sifat-sifat dengan hubungan yang diteliti.

\section{HASIL PENELITIAN DAN PEMBAHASAN}

Peran Notaris Dalam Pembuatan Akta Pembagian Harta Waris Terhadap Ahli Waris Yang Berbeda Agama 
Notaris sebagai pejabat umum diberikan kewenangan oleh undang-undang dalam membuat akta. Dalam hal waris yang diperuntukkan bagi ahli waris non muslim, maka pemberiannya melalui wasiat wajibah, sebagaimana telah dijelaskan pada bab sebelumnya. Hal ini diperkuat oleh pendapat para Ulama Syafi'iyah, Hanafiyah, dan Hanabilah membolehkan berwasiat untuk orang non muslim, dengan syarat yang diberi wasiat tidak memerangi umat Islam. Hal ini mereka qiaskan kepada masalah hibbah dan shadaqah yang diatur dalam Q.S. Mumtahinah [60] : 8, yang artinya: "Allah tidak melarang kamu untuk berbuat baik dan berlaku adil terhadap orang-orang yang tidak memerangimu karena agama dan tidak pula mengusir kamu dari negerimu. Sesungguhnya Allah menyukai orangorang yang berlaku adil."

Demikian pula dapat menjadi landasan yuridis atas pemberian wasiat wajibah kepada ahli waris non muslim oleh Putusan Mahkamah Agung RI Nomor: 368 K/AG/1995, tanggal 16 Juli 1998 yang telah menetapkan bahwa seorang anak perempuan yang beragama Nasrani berhak pula mendapat harta warisan pewaris, tidak melalui warisan melainkan melalui wasiat wajibah. Dan besar perolehannya adalah sama dengan bagian seorang anak perempuan, bukan $1 / 3$ dari harta warisan dan bukan pula $3 / 4$ bagian dari perolehan anak perempuan pewaris.

Selanjutnya Putusan Mahkamah Agung RI Nomor: $51 \mathrm{~K} / \mathrm{AG} / 1999$, tanggal 29 September 1999 yang telah memberikan pertimbangan sebagai berikut: "Menimbang, bahwa namun dengan demikian Mahkamah Agung berpendapat bahwa putusan Pengadilan Tinggi Agama Yogyakarta harus diperbaiki, karena seharusnya Pengadilan Tinggi Agama Yogyakarta memperbaiki amar putusan Pengadilan Agama Yogyakarta mengenai ahli waris non muslim, mereka berhak mendapat warisan melalui wasiat wajibah yang kadar bagiannya sama dengan bagian ahli waris muslim."

Dari dua Putusan Mahkamah Agung RI yang telah di atas dapat ditarik garis hukum sebagai berikut:

a. Beda agama, salah satu sebab untuk tidak salaing mewarisi, apakah perbedaan agama itu antara pewaris dengan ahli waris atau sesame ahli waris.

b. Penyelesaian pembagian harta warisan tergantung kepada agama si pewaris. Bila pewarisnya beragama Islam maka penyelesaian masalah harta warisannya diselesaikan menurut Hukum Kewarisan Islam.

c. Ahli waris yang non muslim dapat menerima bagian dari harta warisan pewaris yang muslim melalui jalan Wasiat Wajibah, tidak melalui jalan warisan.

d. Besarnya bagian ahli waris non muslim yang diperoleh dari harta warisan pewaris dengan jalan wasiat wajibah, bukan $1 / 3$ bagian sebagaimana ketentuan batas maksimal jumlah wasiat, tetapi ahli waris non muslim mendapat bagian yang sama dengan ahli waris yang lain sederajat.

Dalam kaitannya dengan wasiat wajibah kepada ahli waris non muslim, maka notaris sebagai pejabat umum yang diberikan kewenangan oleh UUJN mempunyai peranan dalam membuat akta keterangan wasiat wajibah, dimana tiap testamen tersebut harus berbentuk akta guna mendapatkan kepastian hukum sebagai akta otentik yang mengikat. Dilihat dari pembuatannya oleh seorang Notaris, maka keterangan mewaris melalui wasiat wajibah dapat digolongkan menjadi: ${ }^{8}$

1. Akta relaas, akta pejabat yang pembuatannya dilakukan oleh Notaris, atau;

2. Akta partij, akta yang pembuatannya dilakukan di hadapan Notaris.

Selanjutnya pada pelaksanaan wasiat wajibah bagi ahli waris non muslim, oleh notaris selain mendengarkan maksud tujuan para penghadap, notaris juga dianggap perlu untuk mengajukan beberapa pertanyaan untuk menggali informasi terkait sebelum dibuatkannya akta, serta meminta kelengkapan asli dokumen untuk ditunjukkan pada notaris.

Adapun beberapa dokumen yang menjadi persyaratan tersebut antara lain:

a. Akta Kematian pewaris

b. Kartu Tanda Penduduk penerima waris

c. Surat atau dokumen pendukung lainnya yang membuktikan penerima waris adalah benar merupakan anak dari pewaris, serta dapat dibenarkan secara tertulis dan/ atau lisan pada saat turut menghadap notaris oleh saudara kandung dari penerima waris non muslim melalui wasiat wajibah.

d. Akta atau surat wasiat, jika dalam surat keterangan tersebut dinyatakan bahwa pewaris meninggalkan wasiat.

Setelah persyaratan/dokumen tersebut telah dilakukan pengecekan terhadap legalitasnya, serta mendengarkan keterangan pihak penghadap, maka juga dianggap perlu untuk dibuatkan pernyataan terhadap kebenaran dokumen maupun keterangan pihak penghadap yang dapat dibuat dengan akta notaris ataupun akta dibawah tangan dan

\footnotetext{
${ }^{8}$ G.H.S Lumban Tobing, Op. Cit, hal. 51-52
} 
pernyataan tersebut akan dilekatkan pada minuta akta.

Selanjutnya dituangkannya akta keterangan waris melalui wasiat wajibah dalam bentuk minuta akta. Kemudian oleh notaris akan dibacakan akta keterangan waris tersebut di hadapan para penghadap dan saksi-saksi. Selanjutnya dibagian terakhir melakukan penandatanganan akta keterangan waris tersebut oleh para penghadap dan saksi-saksi serta Notaris.

Kegiatan pembacaan Akta Keterangan Waris di hadapan para penghadap dan saksi-saksi ini pada dasarnya, kegiatan ini adalah dimaksudkan agar para pengahadap dan saksi-saksi mengetahui isi akta. Biasanya, Notaris membacakan isi akta keterangan mewaris secara langsung di hadapan para penghadap dan saksi-saksi. Hanya saja UndangUndang Jabatan Notaris mengatur tentang teknis lain sebagai pengganti pembacaan secara langsung dan harus dinyatakan secara tegas di akhir akta.

Jadi, dalam kasus pelaksanaan wasiat wajibah bagi ahli waris non muslim, notaris mempunyai peranan dalam memberikan pelayanan jasa pembuatan akta otentik sebagaimana yang telah diamanatkan oleh UUJN. Pada akta keterangan waris tersebut di dalamnya menjelaskan mengenai pemberiannya secara wasiat wajibah. Sehingga bagi ahli waris non muslim oleh akta keterangan waris tersebut dapat memberikan kepastian hukum dan memiliki kekuatan pembuktian yang sempurna, baik kekuatan pembuktian lahiriah (uitwendige bewijsracht), kekuatan pembuktian formal (formele bewijsracht) dan kekuatan pembuktian material (materiele bewijsracht). ${ }^{9}$ Dengan demikian ahli waris non muslim memiliki legitimasi dalam mendapatkan bagiannya.

\section{Kelemahan Peran Notaris Dalam Pembuatan Akta Pembagian Harta Waris Terhadap Ahli Waris Yang Berbeda Agama}

Terhadap kelemahan peran notaris terkait pembuatan akta pembagian harta waris terhadap ahli waris non muslim, oleh penulis dalam melakukan wawancara pada salah satu Kantor Notaris di Kabupaten Tegal, pada Kantor Notaris " $\mathrm{X}$ " berpendapat bahwa pembuatan akta pembagian harta waris bagi ahli waris non muslim hanya dapat dilakukan dengan hibah wasiat. Oleh notaris tersebut belum mengenal ketentuan mengenai wasiat wajibah

\footnotetext{
9 Nugraheni, Ilhami \& Harahap, Pengaturan Dan Implementasi Wasiat Wajibah, Mimbar Hukum, Vol. 22, Nomor 2, Juni 2010, hal. 316.
}

dan bagaimana isi akta tersebut dituangkan ke dalam minuta akta.

Begitu pula pada Kantor Notaris " $Y$ ", berpendapat bahwa pemberian harta waris bagi ahli waris non muslim dapat dilaksanakan melalui hibah atau hibah-wasiat, sedangkan wasiat wajibah menurutnya hanya berlaku pada anak angkat saja. Ketentuan tersebut ditambahkan bahwa dalam hal ahli waris non muslim tidak mempunyai hak untuk menerima bagian dari harta warisan melalui pembagian dalam pewarisan.

Dari kunjungan penulis dalam melakukan wawancara tersebut, dapat disimpulkan bahwa kelemahan dari Notaris $X$ dan $Y$ di Kabupaten Tegal yakni karena faktor kurangnya pengetahuan terhadap permasalahan kewarisan, serta tidak melakukan pembaharuan ilmu pengetahuan dalam bidang kenotariatan yang khususnya pada ranah kewarisan, selain itu tidak lepas pula pada faktor salah satu notaris tersebut belum pernah menangani penghadap terkait dalam hal kewarisan, yang juga karena notaris tersebut belum lama membuka praktiknya.

\section{Solusi Terhadap Kelemahan Peran Notaris Dalam Pembuatan Akta Pembagian Harta Waris Terhadap Ahli Waris Yang Berbeda Agama}

Dalam rangka memajukan jabatan notaris tersebut, kiranya oleh notaris semestinya untuk terus melakukan pembaharuan terhadap ilmu pengetahuan khususnya yang berkenaan dengan bidang kenotariatan. Bila terus melakukan update terhadap perkembangan-perkembangan yang ada di bidang kenotariatan justru akan menambah wawasan dan pemahaman bagi notaris tersebut.

Namun hal ini tidak bisa berjalan oleh notaris itu sendiri. Ikatan Notaris Indonesia (INI) sebagai organisasi induk yang menaungi para notaris juga sudah semestinya memiliki peran dalam merangkul notaris agar mampu menjadi notaris profesional dan handal. Peran dari organisasi INI baik pengurus daerah maupun pengurus wilayah dalam hal melakukan suatu kegiatan keilmuan seperti dengan adanya seminar-seminar seputar kenotariatan. Dengan mengadakan kegiatan dalam meningkatkan ilmu pengetahuan dan pembinaan moral anggota notaris.

Akibat dari kemajuan di bidang ekonomi, ilmu pengetahuan dan teknologi membawa dampak naiknya tuntutan terhadap profesionalisme notaris. Apalagi dengan munculnya model perjanjianperjanjian baru yang semakin menuntut notaris 
untuk mampu menjawab tantangan tersebut baik saat ini maupun yang akan datang, dengan menjaga kualitas notaris itu sendiri. Dengan mengadakan pertemuan rutin yang beragendakan pembekalan dan penyegaran pengetahuan secara berkala yang bertujuan untuk berbagi informasi seputar isu-isu hukum terhangat, yang di hadiri oleh narasumber dan stakeholder terkait pula.

Tidak hanya pengembangan ilmu pengetahuan, namun juga dalam hal pembinaan moral juga diperlukan karena berkaitan erat dengan kecerdasan spiritual notaris agar dapat memilah sesuatu yang baik dan sesuatu yang buruk. Sehingga hal tersebut dapat membawa notaris pada kecerdasan intelektual maupun spiritual serta membawa orang pada kebajikan, dan untuk kedepannya jabatan notaris selalu menjadi jabatan yang bermartabat sesuai dengan apa yang diamanatkan oleh undang-undang.

\section{PENUTUP}

\section{Kesimpulan}

1. Peran Notaris Dalam Pembuatan Akta Pembagian Harta Waris Terhadap Ahli Waris Yang Berbeda Agama. Peran notaris dalam membuat akta pembagian harta waris terhadap ahli waris non muslim yakni dengan membuatkan Akta Keterangan Waris yang didalamnya menjelaskan pemberiannya melalui wasiat wajibah. Demikian pula yang menjadi landasan yuridis atas pemberian wasiat wajibah kepada ahli waris non muslim oleh Putusan Mahkamah Agung RI Nomor: 368 K/AG/1995, tanggal 16 Juli 1998 yang telah menetapkan bahwa seorang anak perempuan yang beragama Nasrani berhak pula mendapat harta warisan pewaris, tidak melalui warisan melainkan melalui wasiat wajibah. Dan besar perolehannya adalah sama dengan bagian seorang anak perempuan, bukan $1 / 3$ dari harta warisan dan bukan pula $3 / 4$ bagian dari perolehan anak perempuan pewaris. Selanjutnya Putusan Mahakamah Agung RI Nomor: $51 \mathrm{~K} / \mathrm{AG} / 1999$, tanggal 29 September 1999 yang telah memberikan pertimbangan: "Menimbang, bahwa namun dengan demikian Mahkamah Agung berpendapat bahwa putusan Pengadilan Tinggi Agama Yogyakarta harus diperbaiki, karena seharusnya Pengadilan Tinggi Agama Yogyakarta memperbaiki amar putusan Pengadilan Agama Yogyakarta mengenai ahli waris non muslim, mereka berhak mendapat warisan melalui wasiat wajibah yang kadar bagiannya sama dengan bagian ahli waris muslim."
2. Kelemahan Peran Notaris Dalam Pembuatan Akta Pembagian Harta Waris Terhadap Ahli Waris Yang Berbeda Agama. Dari hasil wawancara penulis, dapat diketahui beberapa kelemahan dari Notaris "X" dan " $Y$ " di Kabupaten Tegal yakni karena faktor kurangnya pengetahuan notaris terhadap isu-isu terkini berkenaan permasalahan kewarisan, serta tidak melakukan pembaharuan ilmu pengetahuan dalam bidang kenotariatan yang khususnya pada ranah kewarisan, selain itu tidak lepas pula pada faktor salah satu notaris tersebut belum pernah menangani penghadap terkait dalam hal kewarisan, yang juga karena notaris tersebut belum lama membuka praktiknya.

3. Solusi Terhadap Kelemahan Peran Notaris Dalam Pembuatan Akta Pembagian Harta Waris Terhadap Ahli Waris Yang Berbeda Agama. Ikatan Notaris Indonesia (INI) sebagai organisasi induk yang menaungi para notaris juga sudah semestinya memiliki peran dalam merangkul notaris agar mampu menjadi notaris profesional dan handal, yaitu dengan melakukan suatu kegiatan keilmuan seperti dengan adanya seminar-seminar seputar kenotariatan. Dengan mengadakan kegiatan dalam meningkatkan ilmu pengetahuan dan pembinaan moral anggota notaris. Akibat dari kemajuan di bidang ekonomi, ilmu pengetahuan dan teknologi membawa dampak naiknya tuntutan terhadap profesionalisme notaris. Apalagi dengan munculnya model perjanjian-perjanjian baru yang semakin menuntut notaris untuk mampu menjawab tantangan tersebut baik saat ini maupun yang akan datang, dengan menjaga kualitas notaris itu sendiri. Dengan mengadakan pertemuan rutin yang beragendakan pembekalan dan penyegaran pengetahuan secara berkala yang bertujuan untuk berbagi informasi seputar isu-isu hukum terhangat, yang di hadiri oleh narasumber dan stakeholder terkait pula dapat menjadi solusi yang baik bagi kemajuan seorang notaris.

\section{Saran}

1. Pada peran notaris dalam membuat akta keterangan waris melalui wasiat wajibah bagi ahli waris non muslim, belum adanya kejelasan mengenai bentuk dan isi yang baku tentang penjelasan wasiat wajibah dalam akta keterangan waris tersebut. Sehingga notaris menginterpretasikannya dengan kemampuan individu dari notaris itu sendiri dalam memformulasikannya ke dalam minuta akta, 
sejauh tidak bertentangan dengan undangundang. Sehingga diperlukan adanya seminar ataupun forum dialog bagi para notaris yang khusus membahas tentang sistematika pembuatan akta keterangan waris dengan wasiat wajibah.

2. Notaris diharapkan agar lebih banyak memahami berbagai aspek yang berkenaan dengan tugas jabatannya dibidang kenotariatan. Sehingga tidak akan ada antara notaris yang satu dengan yang lainnya salah menafsirkan dalam membuat suatu akta otentik.

3. Ikatan Notaris Indonesia (INI) sebagai organisasi induk notaris agar dapat memberikan pembinaan keilmuan bagi notaris dengan tema dan pokok bahasan mengenai isu-isu hukum terbaru agar notaris lebih siap menghadapi berbagai persoalan dan juga dapat menuangkannya dalam minuta akta.
As-Shiddiqi T.M Hasbi, Fiqih Mawaris, Pustaka Rizki Putra, Semarang, 2001

Dahlan Abdul Aziz, Ensiklopedi Hukum Islam, PT Ikhtiar Baru Van Hoeve, Jakarta

Muthiah Aulia, Hukum Islam Dinamika Seputar Hukum Keluarga, Pustaka Baru, 2017

Nugraheni, Ilhami \& Harahap, Pengaturan Dan Implementasi Wasiat Wajibah, Mimbar Hukum, Vol. 22, Nomor 2, Juni 2010

Rusyd Ibnu, Bidayatul Mujtahid, Darul Fikri, Bairut, 1995

Suparman, Fiqih Mawaris Hukum Kewarisan Islam, Gaya Media Pratama, Jakarta, 1997

Syakur Ahmad Bisri, Mudah Memahami Waris Islam, Visimedia Pustaka, Jakarta, 2015

Mudah Memahami Hukum Islam, Visimedia Pustaka, Jakarta, 2015

Tobing G.H.S Lumban, Peraturan Jabatan Notaris, Erlangga, Jakarta, 1999 